DOI 10.37882/2223-2982.2021.02.24

\title{
Н.И. ТУРГЕНЕВ И ЕГО ПРОЕКТ ЛИБЕРАЛЬНОГО ТАЙНОГО ОБЩЕСТВА
}

\section{N.I. TURGENEV AND HIS PROJECT OF A LIBERAL SECRET SOCIETY}

M. Putilin

Summary: The article is devoted to the history of the project of a liberal secret society, which owns its own magazine, conceived by N.I. Turgenev, as well as attempts to implement it. The sources are the writings of Nikolai Ivanovich from the collection "Russia and the Russians", diaries from the collection edited by El Tarasov, as well as the epistolary heritage of Turgenev, published by A.N. Shebunin. As a result of the study carried out in accordance with the concepts of historical-genetic and comparative methods, the history of the origin and development of the project of N.I. Turgenev, as well as its principles, was revealed. This project was based on the dissemination of the principles of liberalism and education through his magazine.

Keywords: 1st quarter of the 19th century, reforms of Alexander I, history of social and political movements in Russia, Decembrist studies, "Arzamas", history of journalism, N.I. Turgenev.

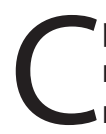

реди отечественных работ, посвященных ранней истории движения декабристов, едва ли можно найти много примеров глубокого анализа деятельности и сочинений Николая Ивановича Тургенева. Среди советских историков выделяется А.Н. Шебунин, осуществивший публикацию писем Николая Ивановича [2] и составивший его краткую биографию [11]. Однако в целом можно говорить о том, что полноценный интерес к личности Н.И. Тургенева возник только в годы Перестройки и дал первые результаты в постсоветской историографии. Среди них стоит особенно отметить работы С.В. Житомирской [5] и В.С. Парсамова [7]. В данных работах Н.И. Тургенев предстал видным идеологом отечественного либерализма начала XIX века. Исследователи нашли убедительные доказательства наличия у Николая Ивановича проработанного проекта учреждения тайного общества, владеющего собственным журналом и способного влиять на общественное мнение.

Вместе с тем, деятельность Николая Ивановича в различных общественных и политических организациях ещё не была рассмотрена в виде целостной картины, что позволило бы уточнить отношение Н.И. Тургенева к реформам Александра I и движению декабристов. Гипотеза статьи состоит в том, что деятельность Н.И. Тургенева в различных организациях была обусловлена наличием у него собственного представления о тайном обществе,
Путилин Михаил Сергеевич

ФГБОУВО «Новосибирский начиональный исследовательский государственный университет» m.s.putilin@bk.ru

Аннотация: Статья посвящена истории проекта либерального тайного общества, владеющего собственным журналом, задуманного Н.И. Тургеневым, а также попыткам его воплощения. В качестве источников привлечены сочинения Николая Ивановича из сборника «Россия и русские», дневники из сборника под редакцией Е.И. Тарасова, а также эпистолярное наследие Тургенева, опубликованное А.Н. Шебуниным. В результате исследования, проведённого в соответствии с концепциями историко-генетического и сравнительного методов, выявлена история зарождения и развития проекта Н.И. Тургенева, а также его принципы. В основе данного проекта было распространение принципов либерализма и просвещения через свой журнал.

Ключевые слова: 1-я четверть XIX в., реформы Александра I, история общественно-политических движений России, декабристоведение, «Арзамас», история журналистики, Н.И. Тургенев.

детали которого мы уточним в процессе анализа, и замысел которого он пронёс через «Арзамас» и тайные общества декабристов.

Развитие инструментария методологии современной исторической науки предполагает широкое применение комплексного подхода на основе различных концепций.

Концепция историко-генетического метода охарактеризована в работе И.Д. Ковальченко «Методы исторического исследования» как наиболее близкая принципу историзма: «Суть его состоит в последовательном раскрытии свойств, функций и изменений изучаемой реальности в процессе ее исторического движения, что позволяет в наибольшей мере приблизиться к воспроизведению реальной истории объекта» [6, с. 170]. Автор отмечал его слабые стороны для современного научного исследования при изучении «массовых исторических явлений и процессов», однако признавал и возможность его успешного применения в сочетании с другими методами [6, с. 172]. Для этого в статье использован также метод сравнительного анализа, необходимый для выявления влияния проекта, задуманного Н.И. Тургеневым, на устав Союза благоденствия.

Цель статьи - на основании анализа источников составить представление о концепции общества, сложив- 
шейся у Н.И. Тургенева, как наилучшей формы организации либеральных сил с целью помощи Александру I и правительству в проведении масштабной программы реформ.

Прежде всего, стоит остановиться на участии Николая Ивановича в литературном обществе «Арзамас» («Арзамас» - литературное общество, объединявшее выдающихся российских деятелей из таких разных сфер общественной и государственной деятельности, как международная дипломатия, литература и журналистика. Работы современных исследователей доказали проправительственный характер данного литературного общества [9]). Мы проанализируем эпистолярное наследие Николая Ивановича и его дневники, в которых нашло отражение его представление о принципах либерального общества, владеющего собственным журналом, которые он пронес через литературное общество «Арзамас» и тайное общество декабристов. Также следует обратиться к «Зелёной книге» для того, чтобы определить степень влияния Н. Тургенева на устав Союза. Общение в кругу «арзамасцев» интересно для статьи тем, что повлияло на политическую позицию Н.И. Тургенева, укрепив его в либеральных проправительственных взглядах. К тому же, именно анализируя причины неудачи «Арзамаса», Н.И. Тургенев окончательно убедился в необходимости общества другого типа, с разносторонними направлениями деятельности, при этом более самостоятельного в выборе метода противостояния противникам реформаторского курса.

Работы современных исследователей доказали проправительственный характер этого литературного общества. В. Г. Сироткин в своей статье [9, с. 3-47] обратил внимание на подготовленный в 1817 г. И. Каподистрией «проект закрепления дипломатического преобладания России в Европе» [9, с. 19]. Автор, обратившись к анализу источников, показал, что члены «Арзамаса» своими сочинениями должны были обеспечить поддержку плана Каподистрии. Задача литераторов состояла в подготовке общественного мнения для принятия реформ, предполагавшихся данным проектом.

М. Майофис в своей ключевой работе [4] более подробно проанализировала источники и охарактеризовала подготовленный И. Каподистрией план как «модернизационный проект» [9, с. 26]. Автор считает, что основные политические меры, предполагавшиеся этим проектом, должны были непосредственно затронуть государственный строй России, а «Арзамас» мог сыграть важную роль В подготовке условий для проведения реформ внутри страны [9, с. 22 - 26].

В.С. Парсамов убедительно показал, что интерес к общественной деятельности у Н. И. Тургенева появился уже в период его заграничной службы в начале 1816 года.
Тогда же, согласно исследователю, будущий декабрист составил программу желательных для России реформ [7], которые, как он надеялся, осуществит Александр I при поддержке общественности. Но дневниковые записи, на которые ссылается Парсамов, не доказывают, что Н. Тургенев имел представления о возможных средствах для реализации подобной программы.

Первые сведения о знакомстве Николая Ивановича с членами «Арзамаса» содержатся в дневниковой записи от 12 ноября 1816 года. Начальное впечатление, сложившееся у Н.И. Тургенева об обществе, не соответствовало его ожиданиям, и поэтому он не возлагал надежд на эту организацию, считая ее неспособной на активную просветительскую деятельность и выпуск журнала социально-политической тематики. Отношение Николая Ивановича к деятельности «арзамасских» литераторов изменялось на протяжении 1816-1817 годов. После первого знакомства с членами «Арзамаса» ему показалось, что они заняты лишь разговорами о необходимых либеральных реформах, но не стремятся способствовать им на практике. Н.И. Тургенев отмечает: «Они говорят, что любят тоже, что и я люблю. Но я этой любви не верю... желают цели, но не желают средств» [1, с. 7]. Николай Иванович упрекнул «арзамасцев» в поисках оправдания для собственного бездействия. После этого автор дневника добавил, что правление Александра I есть удобное время для активной поддержки намеченного правительством реформаторского курса, который не следует упускать мыслящей общественности.

Это невысокое мнение о литературном обществе Н.И. Тургенев сохранял как минимум весь ноябрь 1816 года, потому что почти то же самое он сообщил в письме от 30 ноября 1816 года. Автор конкретизирует характеристику застоя мысли, который он видел как в «Арзамасе», так и в отечественной литературе в целом [2, с. 84]. Какихлибо перспектив для влияния на общественное мнение Николай Иванович в «Арзамасе» ещё не видит, о чем он и заметил в конце письма.

Но немногим более чем через месяц отношение Тургенева к «Арзамасу» стало более снисходительным. Об этом автор написал в письме от 4 января 1817 года, где признал, что после посещения трёх заседаний литературного общества стал подмечать некоторые таланты и достоинства его членов: «Жуковский и Блудов всегда читают речи и очень забавные. Литературные хамы на них всегда сердятся, а они над ними смеются, и дело делают» $[2$, c. 86]. Побывав на нескольких собраниях, Николай Иванович признал в «арзамасцах» способности, с помощью которых можно было противостоять оппонентам в борьбе за общественное мнение, через юмор и пародию.

Оценив ум и талант членов «Арзамаса», Н.И. Турге- 
нев вступил в него, произнеся при этом речь, которую он оценил в письме от 25 февраля 1817 года как «преплохую» [2, с. 89]. Заготовку этой речи Николай Иванович поместил в дневник под запись от 11 января. Эти заготовки посвящены критике журнала «Сын Отечества» и его редактора Н.И. Греча, о чём он сообщил брату в письме, датированном 1 апреля 1817 года [2, с. 92]. Основные претензии, высказанные Тургеневым, связаны с враждебностью к Европе статьи журнала, посвящённой веротерпимости [1, с. 17-20.]. М. Майофис рассматривает эту речь как важный момент в истории литературного общества. Исследователь считает, что после этой речи критика «арзамасцев» перешла от пародий на деятелей «Беседы любителей русского слова» к литературной борьбе с любыми идейными оппонентами [10, с. 323326.]. Отсюда следует, что, увидев в сочленах по обществу единомышленников, Тургенев надеялся на издание их собственного журнала. Источники свидетельствуют о том, что Николай Тургенев вёл в «Арзамасе» активную деятельность, направленную на литераторов, оппонирующих правительственной программе реформ.

Для нас представляет интерес также сделанная в период обсуждения «арзамасских» журнальных проектов (17 июля 1817 года) Н.И. Тургеневым дневниковая запись о тайных обществах: «Общества не умирают... если цель их согласна с законами нравственности и с общею пользою» [1, с. 40.]. Николай Иванович рассуждал о достоинствах политических обществ и сделал вывод об их пользе для борьбы с «деспотическими правлениями». Констатируя успехи немецких обществ, Н.И. Тургенев заключает: «Итак общества, и одни только общества могут приносить действительную и прочную пользу Государствам в отношении нравственного их усовершенствования» $[1$, с. 40]. Таким образом, мы полагаем, что именно в 1817 году, Тургенев пришёл к мысли о необходимости тайных обществ для поддержки реформаторского курса.

В эпистолярном наследии Н.И. Тургенева мы можем найти и другие свидетельства того, что он пытался придать обществу не только литературную, но и политическую значимость. В письме от 8 сентября 1817 года он описал обсуждение в обществе «Арзамас» проекта учреждения собственного журнала. Этот фрагмент очень важен, так как характеризует материалы, предложенные для журнала: «Были предлагаемы программы; все изключительно литературные... я предложил следующую: "показать заслуги Англии и Франции перед Европою"» [2, с. 103.]. Следует отметить, что метод «сравнения заслуг» Николай Иванович задумал использовать для составления некоего публицистического сочинения или статьи ещё в дневниковой записи от 10 августа этого же года. Но там Тургенев думал использовать его против французов, пишущих против Англии: «Многие кричат против Англии, не зная сами за что» [1, с. 43.]. Пересказывая своё предложение для журнала, Николай Иванович не отка- зывался от своих слов о том, что Франция «заставила ненавидеть свободу», но пояснил, что из осмысления уроков революции можно сделать полезные выводы: «Но надобно также упомянуть, что Франция своею революциею прочла так сказать для Европы полный курс науки управления государственного». [2, с. 233.]. Из контекста письма следует, что в этом случае журнал нужен был ему для демонстрации читающей публике достоинств парламентаризма.

Из дневников Николая Ивановича мы можем узнать, что будущий декабрист предпринимал практические шаги по претворению в жизнь собственного видения журнала для «Арзамаса», как позднее для декабристского Союза. В записи от 29 октября Тургенев упомянул о «статьях общей политики», которые он хотел обработать «для Арзамаса» [1, с. 102.]. На основании источников мы можем увидеть активное участие Николая Ивановича в составлении журнала, в числе тем которого должны были быть история идей либерализма и наглядные примеры их успешного воплощения.

Но журнальный проект так и не был осуществлен, само же общество было близко к ликвидации. Об этой ситуации Н.И. Тургенев писал брату в письме от 5 декабря 1817 года «Арзамас наш давно уже не собирается; теперь же, думаю, совсем рушится...» [2, с. 108]. Рассуждая о причинах этого упадка, Николай Иванович назвал основной причиной неудач «Арзамаса» зависимость его членов от своего бюрократического начальства: «У нас все хотят делать вместе, и оттого ничего не делают: хотят и просвещать других и служить...» [3 С. 108.]. В этом случае можно говорить о трансформации взглядов Николая Тургенева. Он разуверился в том, что общество, подобное «Арзамасу» может быть полезно для продвижения реформ в России, несмотря на ум и талант его членов.

Когда стало понятно, что общество «Арзамас» прекратило свое существование, Н.И. Тургенев стал обдумывать возможности продолжить деятельность по продвижению демократических идей в другой организации. Общеизвестным историческим фактом является деятельное участие Николая Тургенева в декабристском тайном обществе под названием Союз благоденствия, а также в более позднем Северном обществе. Союз благоденствия был сформирован в 1818 году, вступление же Н.И. Тургенева в это тайное общество в историографии датируют тем же годом, либо 1819-м, после завершения его работы над сочинением «Опыт теории налогов».

В источниках также сохранились сведения об участии Николая Ивановича в одном из тайных обществ в 1817 году. Среди исследователей до сих пор нет единого мнения об этом тайном обществе. Одни, придерживаясь традиций декабристоведения, отождествляют его с «Орденом русских рыцарей» графа М.И. Дмитриева- 
Мамонова. Другие не видят основания для подобного отождествления и полагают общество Н.И. Тургенева и М.Ф. Орлова самостоятельным, но не реализованным замыслом.

В качестве доказательства существования тайного общества М. Орлова и Н. Тургенева в 1817 году В.В. Пугачёв приводит пушкинскую оду «Вольность», написанную в 1817 году: «...ода «Вольность» была создана до выработки политической программы Союза благоденствия. А между тем она пропагандирует именно ее лозунги» [4, с. 96]. По мнению исследователя, это указывает на заимствование «Зелёной книгой» этих лозунгов из программы, созданной Николаем Тургеневым в 1817 году, вместе с декабристом М.Ф. Орловым, для своего тайного общества. В качестве аргумента В.В. Пугачев ссылается на программу, предложенную Николаем Ивановичем для журнала литературного общества «Арзамас». Демонстрация заслуг Англии и Франции имела целью «показать преимущества представительного правления». Ода «Вольность» является произведением, сочинённым в защиту представительной монархии, причём как от произвола абсолютизма, так и от революционной диктатуры (персонифицированных, соответственно, в образах Павла I и Наполеона Бонапарта). Исследователь утверждает, что причиной этому было знакомство молодого А.С. Пушкина с Н.И. Тургеневым, который стремился объединить российскую либеральную общественность вокруг вопросов о Конституции и парламентской монархии. По мнению В.В. Пугачева, Николай Иванович размышлял о крепостном праве и способах его отмены, но не писал об этом: «"Программа" Тургенева не затрагивала проблемы крепостничества - того, что больше всего интересовало Тургенева» [4, с. 129]. Антикрепостнические сочинения Н.И. Тургенева, вроде «Опыта теории налогов», написаны позже, в период существования Союза благоденствия. Таким образом, исследователь пришёл к выводу о том, что отмену крепостного права Тургенев считал необходимой, но невозможной в качестве цели для тайного общества, поэтому интересующий нас проект тайного общества имел целью поддержку правительственного курса реформ, который должен был привести к принятию Конституции.

Это заключение очень важно для нас, так как предполагает, что Н.И. Тургенев, вероятно, был не только одним из идеологов Союза благоденствия, но и одним из составителей «Зелёной книги». Это прямо указывает на то, что в уставе Союза благоденствия в значительной степени нашёл отражение тургеневский проект либерального политического общества, владеющего печатным изданием и другими рычагами воздействия на общественное мнение.

Для начала следует обратить внимание на вступительную часть к уставу Союза благоденствия. Уже в ней прописан отмеченный исследователем в тексте «Вольности» мотив исправления законов через реформы, в том числе парламентское представительство. В «Зелёной книге» прописана поддержка правительственных реформ: «Союз надеется на доброжелательство правительства, основываясь особенно на следующих изречениях Наказа в бозе почивающей государыни императрицы Екатерины вторыя: «Если умы их недовольно приуготовлены к ним (к законам), то возьмите на себя труд их приуготовить, и вы тем уже много сделаете»»[4, с. 242]. Таким образом, идеологи Союза благоденствия рассчитывали на два этапа борьбы за либеральные реформы законодательства, где первым шагом было формирование общественного мнения в пользу реформ. За эти действия примется тайное общество. Второй этап, состоящий из реализации реформ, осуществится правительством в благоприятной обстановке, над созданием будут работать члены Союза.

Кроме того, если внимательно изучить предполагаемую структуру разделения членов Союза благоденствия по «отраслям», можно увидеть конкретную схему формирования общественного мнения в поддержку реформаторского курса. Особенно показательна в этом плане характеристика третьей «отрасли», которая названа «правосудие». В уставе прописано, что её главной задачей будет борьба с коррупцией: «...чиновников честных и исполняющих свой долг, но бедных состоянием, поддерживает; вознаграждает убытки, за правду понесенные» [4, с. 245]. Но, кроме борьбы с коррупцией в бюрократическом аппарате, третьей «отрасли» в уставе предписано исправлять нравы общества: «Союз старается также укрощать и искоренять властолюбие и презрение прав человеческих...» [4, с. 245]. Соотнеся это с ранее сказанным, здесь можно увидеть не только воспитание в обществе ответственности и уважения к чужим правам, но и формирование негативного общественного мнения по отношению к противникам реформ.

В «Зелёной книге» также присутствуют указания на важность печатных изданий на службе у тайного общества. Самым явным указанием на это является заметка о сфере деятельности «отдела распространения познаний», подчинённого второй «отрасли» Союза благоденствия. Среди прочего этот отдел должен был владеть «повременным изданием», в качестве разделов для которого поименованы в том числе «рассуждения о разных учебных предметах» и «разбор выходящих книг» [4, с. 271]. Здесь имеется прямое указание на журнал, находящийся в собственности членов тайного общества, либо активно сотрудничающий с ними и разделяющий их идеологию.

По собственному признанию Николая Ивановича в автобиографическом сочинении «Записки изгнанника», тайное общество так и не приобрело предписанную 
уставом форму. Основной причиной этого было поверхностное знакомство будущих декабристов с политэкономией и принципами либерализма: «...заметив, что некоторые члены общества нуждаются в политическом образовании, я посоветовал читать... труды, казавшиеся мне особенно подходящими для развития и упорядочения взглядов» [3, с. 58]. Несмотря на старания Николая Тургенева и других декабристских литераторов, не состоялся и выпуск полноценного журнала. А вскоре будущие декабристы разошлись по вопросам цели Союза и способа её достижения, что привело к распаду общества. В возрождённом членами Союза Северном обществе Николай Тургенев значительного участия не принимал, хотя и числился среди участников.

Проследив историю зарождения проекта либерального тайного общества Н.И. Тургенева и попыток его воплощения, мы можем уверенно отметить его постоянство как организационной политической программы. В.В. Пугачев предположил, что причиной тому была политическая дальновидность Николая Ивановича: «Повидимому, это было вызвано опасениями Тургенева, как бы постановка вопроса о крепостном праве... не привела бы к расколу в оппозиционных кругах общественности»[8, с. 129]. Согласно Пугачеву, он изначально задумывал свое тайное общество как возможность для объединения либерального лагеря общественной мысли, с чем вполне можно согласиться. Николай Тургенев был одним из образованнейших людей России своего времени в области экономики и права. Он понимал, почему нельзя включить в программу некоторые спорные моменты.

Следует также обратить внимание на высокую роль журнала в деле распространения идей предполагавшегося Н.И. Тургеневым либерального политического общества. Николай Иванович понимал значение журналистики и стремился объединить в своей тайной организации талантливых литераторов, вроде членов «Арзамаса». Кроме того, это лишний раз подтверждает проправительственный характер Союза благоденствия и политическую прозорливость Николая Тургенева. Печатные издания при императоре Александре I имели либеральный для своего времени цензурный устав, и Тургенев понимал, что эту возможность нельзя упускать. Сейчас мы знаем, что опасения Н.И. Тургенева, подтвердились. После восстания декабристов цензурный устав был сильно ужесточен, и легальная печать внутри России потеряла право выражать какое-либо отношение к политике.

\section{ЛИТЕРАТУРА}

1. Архив братьев Тургеневых. Выпуск 5-й. Дневники и письма Николая Ивановича Тургенева за 1816-1824 годы (III том). Петроград: Академическая двенадцатая типография, $1921-528$ с.

2. Тургенев Н.И. Письма к брату С.И. Тургеневу 1811-1821. // Вступ. ст. А.Н. Шебунин. сост. А.Н. Шебунин, С.Я. Гессен, Н.Г. Свирин. Литературный архив. Издательство Академии наук СССР. М. -Л., 1936.606 с.

3. Тургенев Н.И. Записки изгнанника // Тургенев Н.И. Россия и русские. Перевод с французского С.В. Житомирской. М.: 0.Г.И., 2001. С. 19 - 96.

4. Устав Союза Благоденствия // Избранные социально-политические и философские произведения декабристов / вступит. ст. и общ. ред. И.А. Щипанова; к печати подг. С.Я. Штрайх. М.: Государственное изд-во политической литературы, 1951. С. 237-278.

5. Житомирская С.В. Голос с того света: Книга Николая Тургенева «Россия и русские» - история и судьба // Тургенев Н.И. Россия и русские. Перевод с французского С.В. Житомирской. М.: 0.Г.И., 2001. С. $623-654$.

6. Ковальченко И.Д. Методы исторического исследования / И.Д. Ковальченко. — М.: Наука, 1987. — 440 с.

7. Парсамов В.С. Об отношении Н.И. Тургенева к тайным обществам // Полилог/Polylogos. - 2020. - T. 4. - № 1 [Электронный pecypc]. URL: https://polylog. jes.su/s258770110009759-6-1/ (дата обращения: 05.01.2021). D0I: 10.18254/S258770110009759-6

8. Пугачев В.В. Предыстория Союза благоденствия и пушкинская ода "Вольность" // Пушкин: Исследования и материалы / АН СССР. Ин-т рус. лит. (Пушкин. Дом). — М.; Л.: Изд-во АН СССР, 1962. - Т. 4. - С. 94-139.

9. Сироткин В.Г. Борьба в лагере консервативного русского дворянства по вопросам внешней политики после войны 1812 года и отставка И. Каподистрия в 1822 г. // Проблемы международной дипломатии и освободительных движений. 1975. С. 3-47.

10. Майофис М. Воззвание к Европе: литературное общество «Арзамас» и российский модернизационный проект 1815-1818 годов. М.: Новое литературное обозрение, 2008. -800 c.

11. Шебунин А.Н. Николай Иванович Тургенев / А.Н. Шебунин. М.: Госиздат, 1954. 140 с. 